Article

\title{
The Impact of SARS-CoV-2 Outbreak on the Accommodation Selection of Azorean Tourists. A Study Based on the Assessment of the Azores Population's Attitudes
}

\author{
Rui Alexandre Castanho ${ }^{1,2,3,4,5, * \mathbb{D}}$, Gualter Couto ${ }^{1}\left(\mathbb{D}\right.$, Pedro Pimentel ${ }^{1}\left(\mathbb{D}\right.$, Áurea Sousa ${ }^{6}(\mathbb{D}$, \\ Célia Carvalho ${ }^{7,8}$ and Maria da Graça Batista ${ }^{1}$ \\ 1 School of Business and Economics and CEEAplA, University of Azores, 9500-321 Ponta Delgada, Portugal; \\ gualter.mm.couto@uac.pt (G.C.); pedro.ms.pimentel@uac.pt (P.P.); maria.gc.batista@uac.pt (M.d.G.B.) \\ 2 Faculty of Applied Sciences, WSB University in Dabrowa Górnicza, 41-300 Dabrowa Górnicza, Poland \\ 3 VALORIZA-Research Centre for Endogenous Resource Valorization, 7300 Portalegre, Portugal \\ 4 CITUR-Madeira-Centre for Tourism Research, Development and Innovation, \\ 9000-082 Funchal-Madeira, Portugal \\ 5 Aquageo Ambiente Legal-University of Campinas, Brazil (UNICAMP), Campinas 13083-970, Brazil \\ 6 Faculty of Sciences and Technology and CEEAplA, University of Azores, 9500-321 Ponta Delgada, Portugal; \\ aurea.st.sousa@uac.pt \\ 7 Faculty of Social and Human Sciences, University of Azores, 9500-321 Ponta Delgada, Portugal; \\ celia.mo.carvalho@uac.pt \\ 8 CINEICC - Cognitive and Behavioral Centre for Research and Intervention, Faculty of Psychology and \\ Educational Sciences, University of Coimbra, 3000-115 Coimbra, Portugal \\ * Correspondence: acastanho@wsb.edu.pl
}

Received: 26 October 2020; Accepted: 27 November 2020; Published: 29 November 2020

check for updates

\begin{abstract}
Tourists' intentions show many changing dynamics, both in terms of destination and accommodation selection. These changes in dynamics are seasonal and significantly affected by trends. Therefore, after an infectious disease outbreak, as is the case with COVID-19 caused by a new coronavirus called SARS-CoV-2, these dynamics change on an entirely different level and are so far unknown. Contextual research was conducted to define and analyze the impacts of SARS-CoV-2 on Azores residents' tourism accommodations plans in 2020 by examining their intentions. The most frequent choice was to spend 2020 vacations at the vacation residences of family or friends $(24.3 \%)$, followed by approximately $20 \%$ who chose three- to four-star hotels. A considerable increase in rural tourism accommodation selection intentions was noticed, obtaining the third position with $13.7 \%$, followed by local accommodation (guest house) with $12.1 \%$ of the selection intentions. The study concludes that there are massive consequences of the SARS-CoV-2 crisis at the level of holiday choices and social isolation concerns for this ultra-peripheral territory.
\end{abstract}

Keywords: accommodation preference; Azores Islands; COVID-19 crisis; regional studies; sustainable tourism

\section{Introduction}

The SARS-CoV-2 outbreak at the end of 2019 has demanded profound shifts in our societies [1-6]. Across history, we have witnessed moments of crisis that have always been preceded by moments of transitions. The present state of social, economic, and sanitary dilemmas that we are experiencing appears to be no exception $[7,8]$. Therefore, unprecedented changes are occurring in the tourism industry [9-14]. 
In this regard, many authors and studies state that tourism represents one of the most dynamic economic activities and possibly has the most significant potential for growth in the world $[15,16]$. It is a sector that is increasingly recognized for the great benefits it represents for countries, given its ability to promote and strengthen international relations to generate foreign exchange, create jobs, and potentially contribute to regional development [15-21]. According to the World Travel and Tourism Council [22], it is estimated that this sector contributes $10 \%$ to the world GDP. It generates one in 10 jobs, and its business volume equals or exceeds that of other vital sectors such as exports of oil, food products, or automobiles.

On the other hand, it is a fact that tourists' intentions show many changing dynamics, both in terms of destination and accommodation selection [23-28]. Thus, after an infectious disease outbreak, as is the case with COVID-19, these dynamics change on an entirely different level.

However, many studies and investigations have been conducted and published in the last few years pointing to air travel's decisive role in disseminating contagious diseases, like the one caused by the new coronavirus [29-32]. In this sense, several academics have warned about the possibility of a sanitary crisis shaking society and tourism on a massive scale [32-41]. According to Burkle [42]: "It is also known that the relationships between pandemics and travel are pivotal to understanding health safety and global transformation".

In this regard, in the Azores Region's insular territories, tourism plays a pivotal role in their socioeconomic sphere $[20,21,43,44]$. Therefore, we believe that the consequences of the SARS-CoV-2 pandemic crisis could be even more evident. This study accordingly aimed to respond to the following research problem: "How does the SARS-CoV-2 outbreak influence the accommodation selection of Azorean tourists?".

The aim of this study was to contextually identify and assess the consequences of SARS-CoV-2 over the accommodation selection of Azorean tourists by analyzing public perceptions and, therefore, providing a contribution to the thematic literature.

\section{A Brief Overview about Tourism Crisis Recovery}

After a tourism crisis, if we consider the practical role of managers, the recovery phase's general challenge is to recover operations to normal. According to Scott et al. [45]: “(...) frequently there is evidence of more progressive, strategic thinking in reshaping the offer as social and tourism infrastructure, equipment, and even staff may have to be replaced, new patterns of operation developed, and new markets sought". It is thus evident that seeing tourism as a system has numerous benefits [45].

In this regard, the focus of much of the current research has been on the experiences at the beginning of the crisis, which suddenly led to a disruption of the normal situation, accompanied by the actions needed to re-establish the "normal" state [45].

Authors such as Pearson and Clair [46] in their review of diverse panoramas on the investigation of crises and their development explain the result of a crisis as a system being reestablished to its normal situation. This approach observes the crisis as being different from the rest of the context in which the organization functions, with the importance of the crisis influencing internal technical and social parts of the tourism system running at the time of the crisis experience's origin [45]. From this perspective, restoration is reached by a set of actions or stages. Moreover, an alternative outlook is to recognize crisis events from the perspective of a system where a change, such as a crisis event, causes modifications to its distinct parts. In several cases, these changes have system-wide associations that anticipate returning to the system's pre-crisis stipulations [45,46].

Moreover, Scott et al. [45] state that: "A systems perspective is beneficial as it highlights another variety of consequences or impacts of crises that have not been amply recognized within the tourism literature".

In this context, the studies of Scott and Laws [47,48] explained system resilience, change in system elements, and increases or degeneration in the overall system of tourism due to a crisis. Such studies were corroborated and further developed by Faulkner and Vikulov [49]. The authors used the floods 
in Australia as a case study to measure how a disaster may drive a specific shift in a destination's tourism [45].

In this tourism system, an event's influence as a crisis is perceived as having a greater or lesser scale by all system segments [46-48]. The implication is that a crisis's effects may be shifted beyond system boundaries by organizational ties. Scott et al. [45] provided a very good example: “(...) a baggage handlers' strike at one airport may delay passengers, impose costs on airlines in accommodating passengers, moving luggage and rescheduling flights, and result in extra stress for airport staff. Nevertheless, it may produce follow-on effects at distant airports and cause a loss of business to hotels in those destinations".

Therefore, systemic principles can help the range of stakeholders affected to be recognized and lead to a study of factors determining the speed of recovery, the intensity of effects, and the factors producing the effect $[45,50,51]$.

\section{Methodology}

Considering the scope of this study, diverse approaches and techniques were required, including direct and indirect analysis methods.

Therefore, the methodological procedure was divided into four main steps: survey design, data acquisition, case study analysis, and interpretation of the results, ending with the discussion and conclusions (Figure 1). The last phase focuses on the impact of the SARS-CoV-2 outbreak in the accommodation selection of Azorean tourists and, from there, provides some guidelines and recommendations for the regional tourism actors.

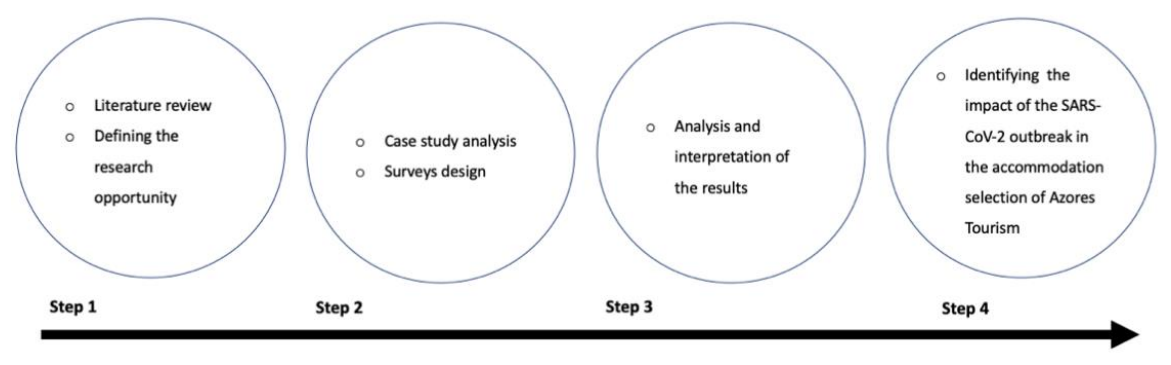

Figure 1. Methodological approach scheme.

In this regard, the Azores Archipelago was used as our case study (Figure 2). Furthermore, considering previous studies that the team conducted on this issue [52-57], it was possible to obtain previous knowledge about this regional actuality, permitting us to collect an even more robust quantity and quality of data. Accordingly, the authors gained a precise understanding of the fundamental issues regarding how this sanitary crisis changes the tourism accommodation selections of tourists living in the Azores Region. This also led to the realization of how this crisis will influence local entrepreneurs and the planned sustainable development of the region.

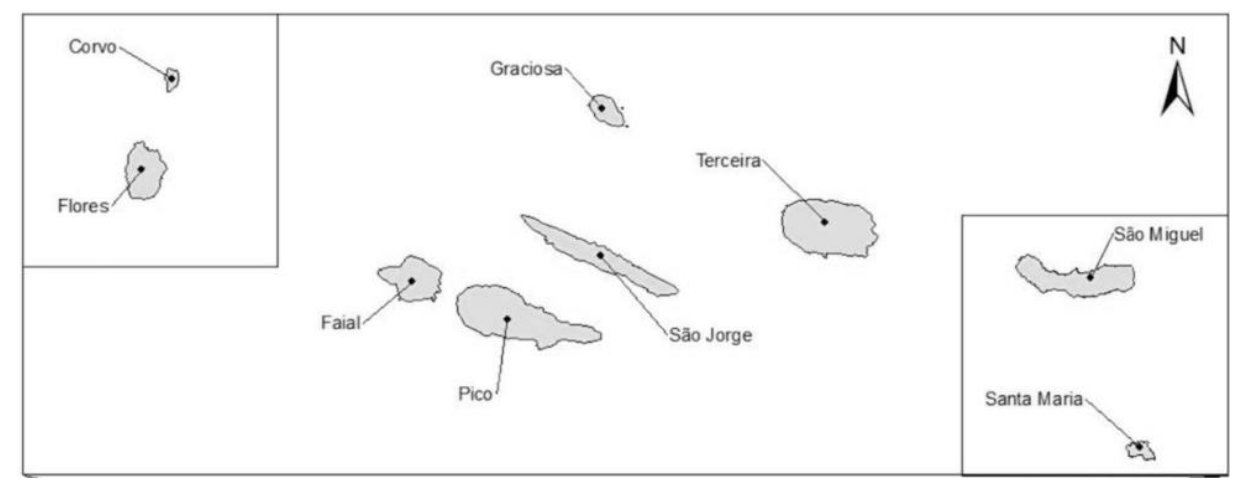

Figure 2. The Azores Archipelago (adapted from: Ferreira [58]). 
Questionnaire Design, Implementation, and Data Treatment

The questionnaires were designed, acknowledging the necessity to conduct web interviews. This type of interview was chosen considering the social distancing requirements of the ongoing pandemic.

The target population was the residents in the Azores Region. The sample was composed of 700 individuals, and the online questionnaires were carried out in the Spring of 2020 (between May and June). This sample was selected once the authors concluded that they were the most relevant sources of knowledge for this study.

Once the data from the questionnaires were collected, statistical methods and tools were used. In the first phase, we used spreadsheets to assemble data, which was then statistically analyzed using Statistical Package for the Social Sciences (IBM SPSS Statistics).

Within the advanced statistical methods used, we should highlight categorical principal component analysis (CATPCA). According to Mori, Kuroda, and Makino [59], principal component analysis (PCA) " (... ) assumes that data are quantitative, and thus it is not directly applicable to qualitative data such as nominal and ordinal data". The current study managed 12 items weighed on an ordinal system. Consequently, a categorical principal component analysis (CATPCA), usually known as nonlinear PCA, was used. These two methods reduce the mentioned variables to diverse uncorrelated possible variables-the principal components. Thus, the CATPCA does not assume that the correlations among variables are linear and incorporates nominal and ordinal variables. CATPCA is therefore a valuable method to examine varied measurement levels of data. Moreover, CATPCA can expose nonlinear correlations amongst variables [59,60]. According to Linting et al. [60], “( . . ) nonlinear PCA can deal with variables at their appropriate measurement level; for example, it can treat Likert-type scales ordinally instead of numerically". Therefore, CATPCA was applied to the 12 mentioned items in the current study, using the varimax rotation with Kaiser normalization and the variable principal normalization method.

\section{Results}

In the first stage of the questionnaire, it was possible to define the participants' sociodemographic characteristics (Tables 1 and 2). Most of the participants were female. The most representational age group was $35-54$ years old (with more than $50 \%$ of the participants), followed by $18-34(24.0 \%)$. More than $60 \%$ of respondents were in a married or in a common-law situation. The most representative professional situation was superior staff, accompanied by intermediate staff, and the least representative was unemployed (with less than 5\%). The most representative educational background was university education, and the least representative was basic education (little more than 5\%). Additionally, the gross annual household income group with the most representative percentage was 15,000-29,999 EUR (more than $40 \%$ ).

If we focus on the participants' island of residence (Table 2), it can be seen that most of them are from the Azores Eastern Group (more than 50\%), more specifically from São Miguel Island.

In this regard, through a five-point Likert scale assessment process, the respondents were asked to declare their agreement with 12 statements, where 1 represents total disagreement and 5 total agreement. Those statements were divided into two groups: (i) A.1 to A.6; and (ii) B.1 to B.6.

The results shown in Table 3 reveal that the most prevalent response (mode) concerning the level of agreement with the statements of items A.1, A.2, A.3, and A.4 was 4 (I agree). In the case of items A.5 and A.6, the mode was 3 (I neither agree nor disagree) and 2 (Disagree), respectively. A.1 was the item with the most significant level of agreement by the participants, so trusting on a "COVID-19 Free" or "Clean and Safe" seal attributed by Portuguese Health Authorities to tourist accommodation is a scored value. On the other hand, the lowest level of agreement was linked to item A.6. The most prevalent response concerning this item was 2 (Disagree), which indicates some optimism on the participants' part about the current situation of COVID-19. If we look to the B items, the highest value of the mode (5-I totally agree) concerning the agreement level with statements was found in the case of item B.3. 
Table 1. Sample features.

\begin{tabular}{|c|c|c|c|}
\hline \multicolumn{2}{|l|}{ Gender } & \multicolumn{2}{|c|}{ Professional Situation } \\
\hline Female & $66.9 \%$ & Unemployed & $4.1 \%$ \\
\hline Male & $33.1 \%$ & Manager & $8.1 \%$ \\
\hline \multicolumn{2}{|l|}{ Age Group } & Student/Trainee & $5.7 \%$ \\
\hline $18-34$ & $24.0 \%$ & Freelancer & $14.0 \%$ \\
\hline $35-54$ & $53.9 \%$ & Intermediate Staff & $30.8 \%$ \\
\hline $55+$ & $22.1 \%$ & Superior Staff & $31.7 \%$ \\
\hline \multicolumn{2}{|c|}{ Marital Status } & Retired & $5.6 \%$ \\
\hline Married or common-law & $64.2 \%$ & \multicolumn{2}{|c|}{ Educational Background } \\
\hline Divorced & $10.3 \%$ & Basic education & $5.1 \%$ \\
\hline Single & $23.4 \%$ & High school & 36.75 \\
\hline Widowed & $2.1 \%$ & University education & $58.1 \%$ \\
\hline \multicolumn{2}{|c|}{ Gross Annual Household Income } & & \\
\hline 15,000 to 29,999 EUR & $43.0 \%$ & & \\
\hline 30,000 to 44,999 EUR & $21.3 \%$ & & \\
\hline 45,000 to 59,999 EUR & $6.4 \%$ & & \\
\hline more than 60,000 EUR & $5.3 \%$ & & \\
\hline less than 15,000 EUR & $24.0 \%$ & & \\
\hline
\end{tabular}

Table 2. Island of Residence.

\begin{tabular}{cc}
\hline Archipelago Group of Residence & $\%$ \\
\hline Eastern Group & $\mathbf{5 4 . 5 \%}$ \\
\hline Central Group & $43.7 \%$ \\
\hline Western Group & $1.9 \%$ \\
\hline Island of Residence & $\mathbf{\%}$ \\
\hline Corvo & $0.3 \%$ \\
\hline Faial & $11.9 \%$ \\
\hline Flores & $1.6 \%$ \\
\hline Graciosa & $0.7 \%$ \\
\hline Pico & $5.0 \%$ \\
\hline Santa Maria & $3.3 \%$ \\
\hline São Jorge & $2.7 \%$ \\
\hline São Miguel & $\mathbf{5 1 . 1} \%$ \\
\hline Terceira & $23.3 \%$ \\
\hline The highest values found are in bold
\end{tabular}


Table 3. Values of mode regarding the degree of agreement with each of the statements A.1 to A.6 and B.1 to B.6.

\begin{tabular}{ccccccc}
\hline & A.1 & A.2 & A.3 & A.4 & A.5 & A.6 \\
\hline Agreement levels & 4 & 4 & 4 & 4 & 3 & 2 \\
& B.1 & B.2 & B.3 & B.4 & B.5 & B.6 \\
Agreement levels & 1 & 2 & 5 & 3 & 4 & 4 \\
\hline
\end{tabular}

A.1. I will trust and choose a tourist accommodation that has a health and hygiene seal as "COVID-19 Free" or "Clean and Safe" assigned by a National institution (Turismo de Portugal) and health authorities; A.2. I will travel relaxed if the use of masks and other individual protections is widespread at the destination; A.3. COVID-19 shows that we must avoid popular tourist destinations; A.4. COVID-19 shows that we should avoid taking vacations during periods of the year with high demand; A.5. COVID-19 shows that it is best to take a vacation in the countryside; A.6. In the future, I will avoid air travel. B.1. Will you spend more on the 2020 vacation than on the 2019 vacation? B.2. Will the 2020 vacation be shorter than the 2019 vacation? B.3. Will you travel less abroad in 2020 than in 2019? B.4. Do you usually choose the cheapest holiday destinations? B.5. Do you usually use cheaper flights to save? B.6. Will you avoid long-term air travel?

Regarding items B.5 and B.6, the most prevalent answers were, in both cases, 4 (I agree). For item B.1, the most prevalent response was 1 (I totally disagree), distinctly revealing the prediction of lower spending on the 2020 vacation, opposed to 2019. In item B.2, the most common answer was 2 (Disagree).

Based on the above data, the Spearman's correlation coefficient values were calculated (Table 4 ). Therefore, positive correlations were identified as statistically significant $(p<0.01)$, and the following correlations higher than 0.3 should be highlighted: A.1 and A.2 $\left(\mathrm{r}_{\mathrm{s}}=0.475 ; p=0.000\right)$; A.3 and A.4 $\left(\mathrm{r}_{\mathrm{s}}=0.797 ; p=0.000\right) ;$ A.3 and A.5 $\left(\mathrm{r}_{\mathrm{s}}=0.588 ; p=0.000\right) ; \mathrm{A} .3$ and A.6 $\left(\mathrm{r}_{\mathrm{s}}=0.400 ; p=0.000\right) ;$ A.4 and A.5 $\left(r_{\mathrm{s}}=0.653 ; p=0.000\right) ;$ A.4 and A.6 $\left(\mathrm{r}_{\mathrm{s}}=0.396 ; p=0.000\right) ;$ A.5 and A.6 $\left(\mathrm{r}_{\mathrm{s}}=0.395 ; p=0.000\right)$.

Table 4. Spearman's correlation coefficient values regarding A.1 to A.6.

\begin{tabular}{ccccccc}
\hline & A.1 & A.2 & A.3 & A.4 & A.5 & A.6 \\
\hline A.1 & 1 & $0.475^{* *}$ & $0.153^{* *}$ & $0.124^{* *}$ & $0.130^{* *}$ & -0.020 \\
\hline A.2 & 1 & $0.112^{* *}$ & $0.126^{* *}$ & $0.167^{* *}$ & -0.014 \\
\hline A.3 & & 1 & $0.797^{* *}$ & $0.588^{* *}$ & $0.400^{* *}$ \\
\hline A.4 & & 1 & $0.653^{* *}$ & $0.396^{* *}$ \\
\hline A.5 & \multicolumn{7}{c}{1} & $0.395^{* *}$ \\
\hline A.6 & \multicolumn{7}{c}{ * Correlation is significant at the 0.01 level (two-tailed). } & 1 \\
\hline \multicolumn{7}{c}{}
\end{tabular}

Table 5 shows the positive and statistically meaningful associations between B.3 and B.6, as well as between B.4 and B.5.

Table 5. Spearman's correlation coefficient values regarding B.1 to B.6.

\begin{tabular}{ccccccc}
\hline & B.1 & B.2 & B.3 & B.4 & B.5 & B.6 \\
\hline B.1 & 1 & 0.074 & $-0.176^{* *}$ & $0.027^{*}$ & -0.035 & -0.011 \\
\hline B. & & 1 & $0.282^{* *}$ & 0.066 & $0.092^{*}$ & $0.132^{* *}$ \\
\hline B.3 & & 1 & $0.146^{* *}$ & $0.233^{* *}$ & $0.405^{* *}$ \\
\hline B.4 & & & 1 & $0.405^{* *}$ & $0.250^{* *}$ \\
\hline B.5 & & & & 1 & $0.290^{* *}$ \\
\hline B.6 & & & & & 1 \\
\hline
\end{tabular}

** Correlation is significant at the 0.01 level (two-tailed); ${ }^{*}$ Correlation is significant at the 0.05 level (two-tailed). 
A question regarding the accommodation type for the 2020 vacation was asked. Bearing in mind that these questions were open and short, 10 options were created due to the considerable quantity of answers (Table 6). Thus, the most frequent choice was to spend 2020 vacation in at the vacation residence of family or friends $(24.3 \%)$, followed by approximately $20 \%$ who chose three- to four-star hotels. A considerable increase in rural tourism accommodation selection intentions was noticed, obtaining the third position with $13.7 \%$, followed closely by guest house with $12.1 \%$ of the selection intentions. A close percentage was found between the number of participants who intended to rent an apartment or residence $(9.5 \%)$ and the participants who stated they will choose their vacation residence $(8.8 \%)$ for their 2020 holiday. The exact same values were identified for the options of camping and/or cruise and five-star hotels-both with $4.3 \%$. Regarding hotels with less than three stars, the observed values were low (2.1\%). Moreover, only $0.8 \%$ of the participants said that they had still not decided on their accommodation type for their 2020 vacation.

Table 6. Accommodation type for 2020 vacation-grouped options.

\begin{tabular}{cc}
\hline Options (1-4) & \% \\
Not decided yet & 0.8 \\
In my vacation residence & 8.8 \\
Apartment or rented house & 9.5 \\
Camping and/or cruise & 4.3 \\
Family or friends' vacation residence & $\mathbf{2 4 . 3}$ \\
Guest house & 12.1 \\
Hotel (less than three stars) & 2.1 \\
Hotel (three to four stars) & 20.1 \\
Hotel (five stars) & 4.3 \\
Rural tourism & 13.7 \\
\hline The highest values found are in bold. &
\end{tabular}

An option selection question was also asked regarding the type of holiday accommodation (Table 7), with three options: (i) tourist accommodation in rural surroundings; (ii) tourist accommodation in an urban environment with green spaces; and (iii) tourist accommodation in an urban environment without green spaces. Even if the results were close, the most selected was option ii (tourist accommodation in an urban environment with green spaces), with $47.8 \%$ of the responses, followed by option $i$ (tourist accommodation in rural surroundings) with $43.8 \%$. The least selected option was tourist accommodation in an urban environment without green spaces (iii), with only $8.4 \%$.

Table 7. Option selection question *.

\begin{tabular}{|c|c|c|c|c|c|}
\hline & Options & Frequency & Percent & $\begin{array}{l}\text { Valid } \\
\text { Percent }\end{array}$ & $\begin{array}{l}\text { Cumulative } \\
\text { Percent }\end{array}$ \\
\hline \multirow{3}{*}{ Valid } & $\begin{array}{l}\text { (i) Tourist accommodation in rural } \\
\text { surroundings }\end{array}$ & 272 & 38.6 & 43.8 & 43.8 \\
\hline & $\begin{array}{l}\text { (ii) Tourist accommodation in an } \\
\text { urban environment with green spaces }\end{array}$ & 297 & 42.2 & 47.8 & 91.6 \\
\hline & $\begin{array}{l}\text { (iii) Tourist accommodation in an urban } \\
\text { environment without green spaces }\end{array}$ & 52 & 7.4 & 8.4 & 100.0 \\
\hline \multirow{3}{*}{ Missing } & Total & 621 & 88.2 & 100.0 & \\
\hline & 99 & 83 & 11.8 & - & - \\
\hline & Total & 704 & 100.0 & - & \\
\hline
\end{tabular}

* In the choice of holiday accommodation, which do you prefer? The highest values regarding the valid percentage found are in bold.

A question about the choice of company for the 2020 vacation (Table 8) was asked. This question has four possible options. Thus, the most selected was in the company of the family ( $56.4 \%)$, followed by traveling as a couple $(28.0 \%)$. The option regarding the company of friends has $8.7 \%$ of the responses and "alone" obtained $6.9 \%$. 
Table 8. Type of company on 2020 vacation.

\begin{tabular}{cccccc}
\hline & Options & Frequency & Percent & Valid Percent & $\begin{array}{c}\text { Cumulative } \\
\text { Percent }\end{array}$ \\
\hline \multirow{4}{*}{ Valid } & Couple & 187 & 26.6 & 28.0 & 28.0 \\
& Family & 377 & 53.6 & 56.4 & 84.4 \\
& Friends & 58 & 8.2 & 8.7 & 93.1 \\
& Alone & 46 & 6.5 & 6.9 & 100.0 \\
\cline { 2 - 4 } Missing & Total & 668 & 94.9 & 100.0 & - \\
& 99 & 36 & 5.1 & - & - \\
& Total & 704 & 100.0 & -
\end{tabular}

A similar question was asked about the expected global spending per group for the 2020 vacation (Table 9). This question has seven possible options-from spending to $300 €$ up to more than $3501 €$. The most verified selected option was from 901 to $1500 €(21.9 \%)$, followed closely by from 301 to $600 €$ (21.4\%). Two options with similar selection values were also up to $300 €(18.2 \%)$ and from 601 to $900 €$ $(17.8 \%)$. The option from 1501 to $2500 €$ was selected by $12.5 \%$ of the respondents, and in the final positions were from 2501 to $3500 €(5.0 \%)$ and more than $3501 €(3.2 \%)$.

Table 9. Global spending per group for the 2020 vacation.

\begin{tabular}{|c|c|c|c|c|c|}
\hline & Options & Frequency & Percent & Valid Percent & $\begin{array}{c}\text { Cumulative } \\
\text { Percent }\end{array}$ \\
\hline \multirow{7}{*}{ Valid } & from 1501 to $2500 €$ & 77 & 10.9 & 12.5 & 12.5 \\
\hline & from 2501 to $3500 €$ & 31 & 4.4 & 5.0 & 17.5 \\
\hline & up to $300 €$ & 112 & 15.9 & 18.2 & 35.7 \\
\hline & from 301 to $600 €$ & 132 & 18.8 & 21.4 & 57.1 \\
\hline & from 601 to $900 €$ & 110 & 15.6 & 17.8 & 74.9 \\
\hline & from 901 to $1500 €$ & 135 & 19.2 & 21.9 & 96.8 \\
\hline & more than $3501 €$ & 20 & 2.8 & 3.2 & 100.0 \\
\hline \multirow{3}{*}{ Missing } & Total & 617 & 87.6 & 100.0 & \\
\hline & 99 & 87 & 12.4 & - & - \\
\hline & Total & 704 & 100.0 & - & \\
\hline
\end{tabular}

The highest values regarding the valid percentage found are in bold.

The expected number of nights at the holiday destination in 2020 was also questioned (Table 10). Here, the participants had four options. The option with the highest percentage of selection was up to six nights (34.3\%). The second and third positions were the options up to eight nights (22.8\%) and up to three nights $(21.9 \%)$. The least selected option was more than 10 nights $(21.0 \%)$.

Table 10. Number of nights at the holiday destination in 2020.

\begin{tabular}{cccccc}
\hline & Options & Frequency & Percent & Valid Percent & $\begin{array}{c}\text { Cumulative } \\
\text { Percent }\end{array}$ \\
\hline \multirow{4}{*}{ Valid } & more than 10 nights & 119 & 16.9 & 21.0 & 21.0 \\
& up to three nights & 124 & 17.6 & 21.9 & 42.9 \\
& up to six nights & 194 & 27.6 & 34.3 & 77.2 \\
Missing & up to eight nights & 129 & 18.3 & 22.8 & 100.0 \\
& Total & 566 & 80.4 & 100.0 & - \\
& 99 & 138 & 19.6 & - & - \\
\hline
\end{tabular}

The highest values regarding the valid percent found are in bold. 
Table 11 shows the results to the question "Are you willing to pay more for a safe vacation?" About $42.3 \%$ of respondents said they are willing to pay more for a safe vacation. It should also be noted that $41.4 \%$ consider this possibility. Only $16.2 \%$ of respondents answered that they were not considering it.

Table 11. Are you willing to pay more for a safe vacation?

\begin{tabular}{|c|c|c|c|c|c|}
\hline & Options & Frequency & Percent & Valid Percent & Cumulative Percent \\
\hline \multirow{3}{*}{ Valid } & No & 108 & 15.3 & 16.2 & 16.2 \\
\hline & Yes & 282 & 40.1 & 42.3 & 58.6 \\
\hline & Maybe & 276 & 39.2 & 41.4 & 100.0 \\
\hline \multirow{3}{*}{ Missing } & Total & 666 & 94.6 & 100.0 & \\
\hline & 99 & 38 & 5.4 & - & - \\
\hline & Total & 704 & 100.0 & - & \\
\hline
\end{tabular}

The highest values regarding the valid percent found are in bold.

Of the 620 respondents who selected at least one of the answer options in the previous table, more than half considered that the "Clean and Safe" seal is essential in the choice of accommodation and restaurants $(75.8 \%)$ and in choosing the destination to visit (50.5\%) (Table 12). Thus, the results suggest that efforts should be made in this regard.

Table 12. When is the "clean and safe" stamp important to you?

\begin{tabular}{ccc}
\hline Options & $\begin{array}{c}\text { Number of } \\
\text { Respondents }\end{array}$ & Percent \\
\hline When choosing accommodation and catering. & $\mathbf{4 7 0}$ & $\mathbf{7 5 . 8 \%}$ \\
When choosing tourist activities. & 173 & $27.9 \%$ \\
When choosing the destination to visit. & 313 & $50.5 \%$ \\
\hline
\end{tabular}

The highest values regarding the valid percent found are in bold.

Using categorical principal component analysis (PCA) on the data submatrix that contains items A.1 to A.6 and B.1 to B.6, five principal components were extracted using the varimax rotation with Kaiser normalization, which explains about $70 \%(22.6 \%, 13.2 \%, 12.6 \%, 11.3 \%$, and $9.9 \%)$ of the data variance (Table 13).

Table 13. Factorial weights matrix-after rotation using the varimax method.

\begin{tabular}{cccccc}
\hline \multicolumn{5}{c}{ Rotated Component Matrix $^{\mathbf{a}}$} \\
\hline & $\mathbf{5}$ & \multicolumn{5}{c}{ Component } \\
\cline { 2 - 6 } & $\mathbf{1}$ & $\mathbf{2}$ & $\mathbf{3}$ & $\mathbf{4}$ & $\mathbf{5}$ \\
\hline A.1 & 0.065 & 0.055 & 0.839 & 0.093 & -0.103 \\
A.2 & 0.066 & 0.023 & 0.847 & -0.029 & 0.177 \\
A.3 & 0.864 & 0.068 & 0.099 & 0.083 & -0.140 \\
A.4 & 0.883 & 0.062 & 0.100 & 0.082 & -0.057 \\
A.5 & 0.811 & 0.035 & 0.125 & 0.062 & 0.024 \\
A.6 & 0.631 & 0.135 & -0.198 & 0.050 & 0.253 \\
B.1 & 0.013 & 0.030 & 0.073 & 0.028 & 0.877 \\
B.2 & 0.087 & -0.052 & 0.030 & 0.838 & 0.255 \\
B.3 & 0.091 & 0.230 & 0.052 & 0.683 & -0.428 \\
B.4 & 0.129 & 0.795 & -0.022 & -0.038 & 0.109 \\
B.5 & -0.014 & 0.812 & 0.090 & 0.090 & -0.050 \\
B.6 & 0.298 & 0.459 & 0.024 & 0.384 & -0.180 \\
\hline
\end{tabular}

a Rotation converged in five iterations. Extraction method: categorical principal component analysis. Rotation method: varimax with Kaiser normalization. 
The items mostly related to the first main comment are items A.3, A.4, A.5, and A.6, so this component was called "social isolation". The second dimension's most important items are items B.4, B.5, and B.6, which is why this component was called "search for cheaper travel options". Items A.1 and A.2 are the items that most contribute to the explanation of dimension 3, which is why this dimension was called "security". The items most related to dimension four are items B.2 and B.3, so this dimension was called "repercussions of COVID-19 at the level of holidays". Finally, the fifth main component was called "vacation expenditures, compared to 2019" because item B.1 is the most essential item for this dimension.

\section{Discussion and Conclusions}

In the current context of the pandemic, we have seen an abrupt fall in economic activity. Consumption decreased due to quarantines and decreased incomes on the part of the population. Production slowed due to the fall in demand, the fact that workers were retained at home, and also due to a lack of intermediate and investment goods.

In this context, the financial situation of businesses and individuals is degraded, especially in sectors most exposed to the immediate effects of the crisis, such as tourism.

The economic impact of the health crisis will depend greatly on the responses undertaken at different levels: individual behavior, businesses and workers, national governments, and international entities.

The message "COVID-19 Free" or the "Clean and Safe" seal attributed by Portuguese Health Authorities to tourist accommodation was the item with the most significant level of agreement by the survey participants. On the other hand, the lowest level of agreement was linked to the item "In the future, I will avoid air travel", which reflects that people do not want to stop traveling. There is some optimism on the part of the participants about the current situation of COVID-19.

The most frequent answers concerning the agreement level with statements were found in the case of item "Will you travel less abroad in 2020 than in 2019?". The tourists want cheaper flights to save and avoid long-term air travel. This study reveals a prediction of lower spending on 2020 vacations, as opposed to 2019.

Thus, the most frequent choice was to spend 2020 vacations in a family or friends' vacation residence, followed by three- to four-star hotels. A considerable increase in rural tourism accommodation selection intentions was noticed, obtaining the third position, followed closely by guest house accommodation. Tourist accommodation in an urban environment with green spaces was the most selected option.

About $42.3 \%$ of respondents said they are willing to pay more for a safe vacation. Dimension security is essential nowadays in this sector. The "Clean and Safe" seal is essential in choosing accommodation, restaurants, and the destination to visit. Thus, the results suggest that efforts should be made in this regard. We conclude that there are tremendous repercussions of COVID-19 at the level of holiday choices and social isolation matters.

However, and considering the thematic literature, more specifically the studies of Faulkner and Vikulov [49], a crisis may drive a specific shift in a destination's tourism, which is not necessarily for the worst. Furthermore, several other relevant studies that analyzed similar phenomena also should be considered for this specific issue (see: Wen et al. [61], Melly and Hanrahan [62], Dai et al. [63], Boğan, Dedeoğlu and Dedeoğlu [64], and Fakfare and Wattanacharoensil [65] as just a few examples.

Thus, the main actors and regional decision-makers should use this moment to envision a more sustainable prospect for the Azores territory.

\section{Limitations and Prospective Research Lines}

Though this investigation extends our comprehension of how the impacts of the SARS-CoV-2 outbreak influenced the accommodation selection preferences of Azorean tourists, critical perspectives for future research remain. 
For example, this study only covers an initial timeline of the virus outbreak (May/June of 2020). Therefore, and considering that the pandemic crisis will last longer, similar studies should be continued to be conducted in the upcoming months to monitor the tourists' perceptions and attitudes regarding the accommodation selection in the crisis period and beyond.

Furthermore, even if this study provides some significant outlooks on the impacts of the SARS-CoV-2 outbreak's influence on the accommodation selection preferences of Azorean tourists, if more insular territories were studied, it would provide more complete outcomes for this issue on a worldwide scale.

Author Contributions: Conceptualization, R.A.C. and C.C.; methodology, P.P.; software, Á.S.; formal analysis, Á.S.; investigation, M.d.G.B.; resources, G.C.; data curation, Á.S., C.C. and M.d.G.B.; writing-original draft preparation, R.A.C.; writing - review and editing, R.A.C. and P.P.; visualization, M.d.G.B.; project administration, G.C.; funding acquisition, G.C. All authors have read and agreed to the published version of the manuscript.

Funding: This paper is financed by Portuguese national funds through FCT-Fundação para a Ciência e a Tecnologia, I.P., project number UIDB/00685/2020 and also by the project GREAT—Genuine Rural Experiences in the Azores Tourism with the code: ACORES-01-0145-FEDER-000089.

Conflicts of Interest: The authors declare no conflict of interest.

\section{References}

1. Abud, D. Essay: Covid-19. Effects in the International Trade of Rep. Dominican and Other Latin American Countries. Special Issue of: Reflexiones Sobre el Coronavirus y sus Impactos in Revista Científica Monfragüe Resiliente-Scientific Journal. 2020, pp. 26-29. Available online: https://www.eweb.unex.es/eweb/ monfragueresilente/Monografico\%20Covid\%2019.pdf (accessed on 14 July 2020).

2. CEPAL-Comisión Económica para América Latina y el Caribe. América Latina y el Caribe ante la Pandemia del COVID-19. 2020. Available online: https://repositorio.cepal.org/bitstream/handle/11362/45337/4/S2000264_es. pdf (accessed on 14 July 2020).

3. FAO. The Impacts of COVID-19 on the Forest Sector: How to Respond? FAO: Rome, Italy, 2020. [CrossRef]

4. Gutiérrez, S. Essay: After the Pandemic, Mobility After Covid-19. Special Issue of: Reflexiones Sobre el Coronavirus y Sus Impactos in Revista Científica Monfragüe Resiliente-Scientific Journal. 2020, pp. 13-16. Available online: https://www.eweb.unex.es/eweb/monfragueresilente/ (accessed on 14 July 2020).

5. Mora Aliseda, J. El Coronavirus Obliga a una Respuesta Sin. Fronteras Special Issue of: Reflexiones Aobre el coronavirus y sus Impactos in Revista Científica Monfragüe Resiliente-Scientific Journal. 2020, pp. 6-8. Available online: https://www.eweb.unex.es/eweb/monfragueresilente/Monografico\%20Covid\%2019.pdf (accessed on 14 July 2020).

6. Ramírez-Silva, J.P. Una Óptica Sustentable del Turismo Post Covid-19. Special Issue of: Reflexiones Sobre el Coronavirus y Sus Impactos in Revista Científica Monfragüe Resiliente-Scientific Journal. 2020, pp. 104-112. Available online: https://www.eweb.unex.es/eweb/monfragueresilente/ (accessed on 14 July 2020).

7. Espinoza, D. La Propuesta de Trabajo de Costa Rica Para Atender en la Crisis Pandémica por el SARS-COV-2 y la Participación de las Universidades Estatales. Special Issue of: Reflexiones Sobre el Coronavirus y Sus Impactos in Revista Científica Monfragüe Resiliente-Scientific Journal. 2020, pp. 66-80. Available online: https://www.eweb.unex.es/eweb/monfragueresilente/ (accessed on 14 July 2020).

8. Castanho, R.A. A Pandemic Crisis Shocking Us All: The Covid-19. Special Issue of: Reflexiones Sobre el coronavirus y Sus Impactos in Revista Científica Monfragüe Resiliente-Scientific Journal. 2020, pp. 233-238. Available online: https://www.eweb.unex.es/eweb/monfragueresilente/ (accessed on 14 July 2020).

9. Abu Bakar, N.; Rosbi, S. Effect of Coronavirus disease (COVID-19) to tourism industry. Int. J. Adv. Eng. Res. Sci. 2020, 7, 189-193. [CrossRef]

10. Mckibbin, W.; Roshen, F. The economic impact of COVID-19. In Economics in the Time of COVID-19; Publisher: Centre for Economic Policy Research; CEPR Press: London, UK, 2020.

11. OECD. The Impact of the Coronavirus (COVID-19) Crisis on Development Finance. Available online: https://read.oecd-ilibrary.org/view/?ref=134_134569-xn1go1i113\&title=The-impact-of-the-coronavirus(COVID-19)-crisis-on-development-finance (accessed on 21 July 2020). 
12. Ranasinghe, R.; Damunupola, A.; Wijesundara, W.; Karunarathne, C.; Nawarathna, D.; Gamage, S.; Ranaweera, A.; Idroos, A. Tourism After Corona: Impacts of Covid 19 Pandemic and Way Forward for Tourism, Hotel and Mice Industry in Sri Lanka. SSRN Electron. J. 2020. [CrossRef]

13. Sigala, M. Tourism and COVID-19: Impacts and implications for advancing and resetting industry and research. Journal of business research. J. Bus. Res. 2020, 117, 312-321. [CrossRef] [PubMed]

14. UN. Covid-19 and Tourism: Assessing the Economic Consequences. Available online: https://unctad.org/en/ PublicationsLibrary/ditcinf2020d3_en.pdf (accessed on 31 August 2020).

15. Santos, R. O Regresso Dos Emigrantes Portugueses e o Desenvolvimento do Turismo em Portugal. Ph.D. Thesis, University of Aveiro, Aveiro, Portugal, 2013.

16. Fernández-Jeri, A. El Comportamiento del Consumidor Convencional de Alimentos Durante el COVID-19, en el Perú. Special Issue of: Reflexiones Sobre el Coronavirus y Sus Impactos in Revista Científica Monfragüe Resiliente-Scientific Journal. 2020, pp. 86-92. Available online: https:/www.eweb.unex.es/ eweb/monfragueresilente/ (accessed on 14 July 2020).

17. Labrianidis, L.; Ferrão, J.; Hertzina, K.; Kalantaridis, C.; Piasecki, B.; Smallbone, D. The Future of Europe's Rural Periphery; Final Report; 5th Framework Programme of the European Community; Routledge: Thames, UK, 2003.

18. Sharpley, R.; Vass, A. Tourism, farming and diversification: An attitudinal study. Tour. Manag. 2006, 27, 1040-1052. [CrossRef]

19. Chen, K.; Yang, H. Appraising the economic impact of the opening up to mainland Chinese tourist arrivals' policy on Taiwan with a tourism-CGE model. Asia Pac. J. Tour. Res. 2010, 15, 155-175. [CrossRef]

20. Santos, R.; Castanho, R.A.; Lousada, S. Return Migration and Tourism Sustainability in Portugal: Extracting Opportunities for Sustainable Common Planning in Southern Europe. Sustainability 2019, 11, 6468. [CrossRef]

21. Santos, R.; Castanho, R.A.; Lousada, S. The Portuguese Emigrants' Return and the Impacts over Tourism Development in Rural Areas: Directions for a Sustainable Planning. In Espacios y Sociedades en Transformación. Ed. Thomson Reuters Aranzadi-Spain; Chapter 5; pp. 85-100. ISBN 978-84-1346-693-4. Available online: https://www.researchgate.net/publication/333603210_The_Portuguese_Emigrants_Return_and_the_ Impacts_over_Tourism_Development_in_Rural_Areas_Directions_for_a_Sustainable_Planning (accessed on 21 July 2020).

22. World Travel and Tourism Council (WTTC). Economic Impact Reports. 2019. Available online: https: //wttc.org/Research/Economic-Impact. (accessed on 21 July 2020).

23. Oppermann, M. Tourism Destination Loyalty. J. Travel Res. 2000, 39, 78-84. [CrossRef]

24. Yavas, U.; Babakus, E. Dimensions of hotel choice criteria: Congruence between business and leisure travelers. Int. J. Hosp. Manag. 2005, 24, 359-367. [CrossRef]

25. Enrique Bigné, J.; Mattila, A.S.; Andreu, L. The impact of experiential consumption cognitions and emotions on behavioral intentions. J. Serv. Mark. 2008, 22, 303-315. [CrossRef]

26. Žabkar, V.; Brenčič, M.; Dmitrović, T. Modelling perceived quality, visitor satisfaction and behavioural intentions at the destination level. Tour. Manag. 2010, 31, 537-546. [CrossRef]

27. Chin, C.H.; Law, F.L.; May, C.; Ramayah, T. The Impact of Accessibility Quality and Accommodation Quality on Tourists' Satisfaction and Revisit Intention to Rural Tourism Destination in Sarawak: The Moderating Role of Local Communities' Attitude. GBMR 2018, 10, 115-127.

28. Aruan, D. Factors influencing travelers' behavioral intentions to use P2P accommodation based on trading activity: Airbnb vs Couchsurfing. Int. J. Cult. Tour. Hosp. Res. 2019, 13, 487-504. [CrossRef]

29. Tatem, A.J.; Rogers, D.J.; Hay, S.I. Global transport networks and infectious disease spread. Adv. Parasitol. 2006, 62, 293-343. [CrossRef] [PubMed]

30. Wilson, M. Global Travel and Emerging Infections. Infectious Disease Movement in a Borderless World: Microbial Threats Forum, Institute of Medicine, Workshop Summary; National Academies Press: Washington, DC, USA, 2010; pp. 90-104.

31. Brown, A.; Ahmad, S.; Beck, C.; Nguyen-Van-Tam, J. The roles of transportation and transportation hubs in the propagation of influenza and coronaviruses: A systematic review. Travel Med. 2016, 23, tav002. [CrossRef]

32. Rosselló, J.; Santana-Gallego, M.; Awan, W. Infectious disease risk and international tourism demand, Health Policy and Planning. Heal. Policy Plan. 2017, 32. [CrossRef]

33. Gossling, S. Global environmental consequences of tourism. Glob. Environ. Chang. 2002, 12, $283-302$. [CrossRef] 
34. Hall, C.M. Tourism, biodiversity and global environmental change. In Tourism and Global Environmental Change: Ecological, Economic, Social and Political Interrelationships; Go€ssling, S., Hall, C.M., Eds.; Routledge: Abingdon, UK, 2006; pp. 142-156.

35. Page, S.; Yeoman, I. How Visit Scotland prepared for a flu pandemic. J. Bus. Contin. Emer. Plan. 2007, 1, 167-182.

36. Fauci, A.S.; Morens, D.M. The perpetual challenge of infectious diseases. New Engl. J. Med. 2012, 366, 454-461. [CrossRef]

37. Scott, D.; Gosssling, S. What could the next 40 years hold for global tourism? Tour. Recreat. Res. 2015, 40, 269-285. [CrossRef]

38. Qureshi, A. Economic and Political Impact of Ebola Virus Disease. In Ebola Virus Disease; Academic Press: Cambridge, MA, USA, 2016; Chapter 13; pp. 177-191. ISBN 9780128042304. [CrossRef]

39. Abukhalifeh, A.; Faller, E.; Ahmad, A.; Tadros, S. Current Issue in Tourism: Diseases Transformation as a Potential Risks for Travellers. Glob. Stoch. Anal. 2017, 5, 7.

40. Qiu, W.; Chu, C.; Mao, A.; Wu, J. The Impacts on Health, Society, and Economy of SARS and H7N9 Outbreaks in China: A Case Comparison Study. J. Environ. Public Heal. 2018, 2018, 1-7. [CrossRef] [PubMed]

41. Bloom, D.E.; Cadarette, D. Infectious disease threats in the 21st Century: Strengthening the global response. Front. Immunol. 2019, 10, 549. [CrossRef] [PubMed]

42. Burkle, F.M. Globalization and disasters: Issues of public health, state capacity and political action. J. Int. Aff. 2006, 59, 231-265.

43. Castanho, R.A.; Lousada, S.; Camacho, R.; Naranjo Gómez, J.; Loures, L.; Cabezas, J. Ordenamento territorial e a sua relação com o turismo regional: O Caso de Estudo da Região Autónoma da Madeira (RAM). CIDADES Comunidades e Territ. 2018. [CrossRef]

44. Naranjo Gómez, J.M.; Lousada, S.; Velarde, J.G.; Castanho, R.A.; Loures, L. Land-use changes in the canary archipelago using the CORINE data: A retrospective analysis. Land 2020, 9, 232. [CrossRef]

45. Scott, N.; Laws, E.; Prideaux, B. Tourism Crises and Marketing Recovery Strategies. J. Travel Tour. Mark. 2008, 23, 1-13. [CrossRef]

46. Pearson, C.M.; Clair, J.A. Reframing crisis management. Acad. Manag. Rev. 1998, 23, 59-76. [CrossRef]

47. Scott, N.; Laws, E. Whale watching-the roles of small firms in the evolution of a new Australian niche market. In Small Firms in Tourism: International Perspectives; Thomas, R., Ed.; Elsevier: London, UK, 2004; pp. 153-166.

48. Scott, N.; Laws, E. Stimulants and inhibitors in the development of niche markets-The whale' stale. In Proceedings of the CAUTHE 2004, Brisbane, Australia, 9-12 February 2004.

49. Faulkner, B.; Vikulov, L. Katherine, washed out one day, back on track the next: A post-mortem of a tourism disaster. Tour. Manag. 2001, 22, 331-344. [CrossRef]

50. Armstrong, E.K.; Ritchie, B.W. The Heart Recovery Marketing Campaign: Destination Recovery after a Major Bushfire in Australia's National Capital. J. Travel Tour. Mark. 2007, 23, 175-190. [CrossRef]

51. Carlsen, J.; Hughes, M. Tourism Market Recovery in the Maldives After the 2004 Indian Ocean Tsunami. J. Travel Tour. Mark. 2008, 23, 139-149. [CrossRef]

52. Vieira, J.; Couto, G.; Pimentel, P.; Menezes, A.; Moniz, A.; Sousa, F. The Satisfaction of the Nordic Tourist with the Azores as a Destination. Scand. J. Hosp. Tour. 2013, 13, 58-72. [CrossRef]

53. Couto, G.; Pimentel, P.; Ponte, J. Tourism Development Potential in an Insular Territory: The Case of Ribeira Grande in the Azores. J. Tour. Res. Hosp. 2017, 6. [CrossRef]

54. Castanho, R.A.; Couto, G. Pimentel. Principles of Sustainable Tourism and Cultural Management in Rural and Ultra-peripheral Territories: Extracting Guidelines for its application in the Azores Archipelago. Cult. Manag. Sci. Educ. 2020, 4, 9-24. [CrossRef]

55. Castanho, R.A.; Couto, G.; Pimentel, P.; Carvalho, C.; Sousa, Á. Territorial Management and Governance, Regional Public Policies and their Relationship with Tourism. A Case Study of the Azores Autonomous Region. Sustainability 2020, 12, 6059. [CrossRef]

56. Couto, G.; Castanho, R.A.; Sousa, Á.; Pimentel, P.; Santos, C.; Carvalho, C. The Impacts of COVID-19 Crisis over the Tourism Expectations of the Azores Archipelago Residents. Sustainability 2020, 12, 7612. [CrossRef]

57. Castanho, R.A.; Couto, G.; Pimentel., P.; Carvalho, C.; Sousa, Á.; Garrido Velarde, J. Assessing the impacts of public policies over tourism in Azores Islands. A research based on tourists and residents perceptions. WSEAS Trans. Environ. Dev. 2020, 16. [CrossRef] 
58. Ferreira, H.M. Diversity Patterns of Honey Bee (Apis Mellifera L.) Populations from the Archipelago of the Azores: Insights from Mtdna and Wing Geometric Morphometrics. Master Thesis, University of Porto, Porto, Portugal, 2017.

59. Mori, Y.; Kuroda, M.; Makino, N. Nonlinear Principal Component Analysis and Its Applications; Springer: New York, NY, USA, 2016.

60. Linting, M.; Meulman, J.J.; Groenen, P.J.F.; van der Kooij, A.J. Nonlinear principal components analysis: Introduction and application. Psychol. Methods 2007, 12, 336-358. [CrossRef]

61. Wen, J.; Kozak, M.; Yang, S.; Liu, F. COVID-19: Potential effects on Chinese citizens' lifestyle and travel. Tour. Rev. 2020. [CrossRef]

62. Melly, D.; Hanrahan, J. Tourism biosecurity risk management and planning: An international comparative analysis and implications for Ireland. Tour. Rev. 2020. [CrossRef]

63. Dai, Y.D.; Zhuang, W.L.; Lu, S.C.; Huan, T.C. Work engagement or job burnout? Psychological ownership amongst the employees of international tourist hotels. Tour. Rev. 2020. [CrossRef]

64. Boğan, E.; Dedeoğlu, B.B.; Dedeoğlu, S.B. The effect of residents' perception of hotel social responsibility on overall attitude toward tourism. Tour. Rev. 2020. [CrossRef]

65. Fakfare, P.; Wattanacharoensil, W. Impacts of community market development on the residents' well-being and satisfaction. Tour. Rev. 2020. [CrossRef]

Publisher's Note: MDPI stays neutral with regard to jurisdictional claims in published maps and institutional affiliations. 